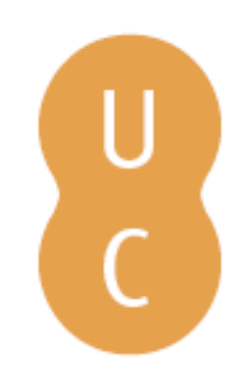

\title{
pompalina
}

\section{Rainfall effects on fine forest fuels moisture content}

Autor(es): $\quad \begin{array}{ll}\text { Lopes, Sérgio; Viegas, Domingos Xavier; Lemos, Luís de; Viegas, Maria } \\ \quad \text { Teresa }\end{array}$

Publicado por: Imprensa da Universidade de Coimbra

URL

persistente: URI:http://hdl.handle.net/10316.2/34347

DOI: $\quad$ DOI:http://dx.doi.org/10.14195/978-989-26-0884-6_137

Accessed : $\quad$ 26-Apr-2023 12:29:02

A navegação consulta e descarregamento dos títulos inseridos nas Bibliotecas Digitais UC Digitalis, UC Pombalina e UC Impactum, pressupõem a aceitação plena e sem reservas dos Termos e Condições de Uso destas Bibliotecas Digitais, disponíveis em https://digitalis.uc.pt/pt-pt/termos.

Conforme exposto nos referidos Termos e Condições de Uso, o descarregamento de títulos de acesso restrito requer uma licença válida de autorização devendo o utilizador aceder ao(s) documento(s) a partir de um endereço de IP da instituição detentora da supramencionada licença.

Ao utilizador é apenas permitido o descarregamento para uso pessoal, pelo que o emprego do(s) título(s) descarregado(s) para outro fim, designadamente comercial, carece de autorização do respetivo autor ou editor da obra.

Na medida em que todas as obras da UC Digitalis se encontram protegidas pelo Código do Direito de Autor e Direitos Conexos e demais legislação aplicável, toda a cópia, parcial ou total, deste documento, nos casos em que é legalmente admitida, deverá conter ou fazer-se acompanhar por este aviso.

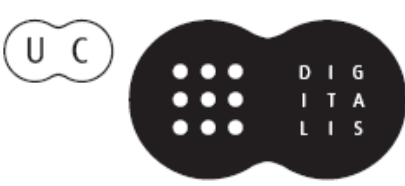




\section{ADVANCES IN}

Forest Fire

\section{RESEARCH}

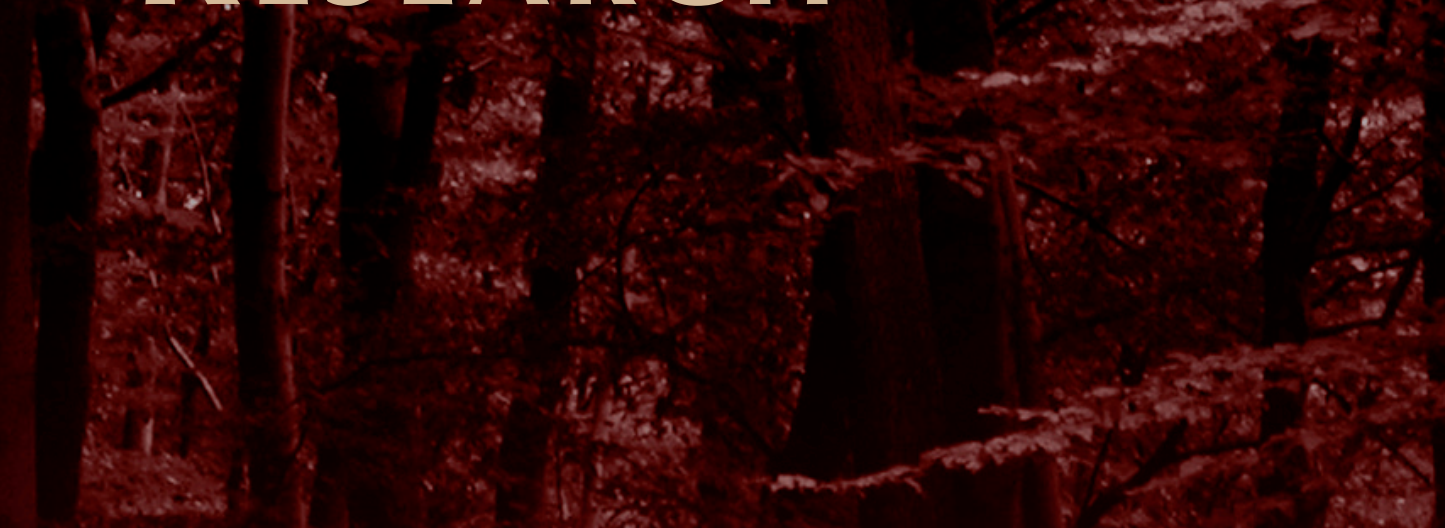

\section{DOMINGOS XAVIER VIEGAS}

\section{EDITOR}




\title{
Rainfall effects on fine forest fuels moisture content
}

\author{
Sérgio Lopes ${ }^{\mathrm{a}}$, Domingos Xavier Viegas ${ }^{\mathrm{b}}$, Luís de Lemos $^{\mathrm{a}}$, Maria Teresa Viegas ${ }^{\mathrm{b}}$ \\ ${ }^{a}$ Environment Department, Technology and Management School of Viseu, Polytechnic Institute of \\ Viseu, Campus Politécnico de Repeses 3504-510 Viseu, Portugal;slopes@estv.ipv.pt \\ ${ }^{b}$ ADAI/Mechanical Engineering Department, University of Coimbra, Polo II, Pinhal de Marrocos, \\ 3030-790 Coimbra, Portugal; xavier.viegas@dem.uc.pt
}

\begin{abstract}
The main purpose of the present study was to develop and test different approaches to predict fuel moisture content after rainfall episodes based on field measurements. These approaches were validated also with field measurements that indicate which as the best performance. It was also an objective to establish a low risk or safe period in terms of forest fires occurrence through the analyses of fuel moisture content after rainfall episodes comparatively to the value observed before the episodes.

Although the influence of rainfall on forest fuel moisture content is quite complex we found that the simplified assumptions made in the present study and the simple mathematical models that were proposed exhibit suitable performances in the prediction of fuel moisture content change after rainfall episodes. In the present study good prediction results were obtain for dead foliage of the tree species of Pinus pinaster and Eucalyptus globulus. It was also verified that a safe time period regarding the occurrence of forest fires depending on the summer rainfall episode intensity could be established.
\end{abstract}

Keywords: Fuels, moisture content, rainfall, fire risk.

\section{Introduction}

Rainfall has a significant effect in forest fire danger. Depending on the period of the year, it can contribute to increase fine fuel growth and therefore increase fire danger during the fire season (Viegas and Viegas 1994). On the other hand rainfall episodes during the fire season will increase fuel moisture content (FMC) and therefore reduce fire danger, establishing a low risk period regarding the occurrence of forest fires. In order to predict FMC it is important to estimate the increase of moisture as a result of a given amount of rainfall and also to predict the decrease of moisture and consequently the duration of the low risk period. The influence of rainfall on FMC of dead fine fuels is well known but it is a complex process that cannot be simply a matter of directly equating the changes in moisture content with the amount of rainfall (Viney 1991).

The increase of FMC can decrease with the increase of rainfall amount and initial FMC. Thus as the amount of rainfall increases, a smaller proportion of it could be held by the fuels, also the higher the fuel's initial moisture content, the less rain it could absorb (Van Wagner 1987).

The main purpose of the present study is to develop and test different approaches to predict FMC after rainfall episodes based on field measurements. These approaches will be validated also with field measurements that will indicate which as the best performance. It is also an objective to establish a safe time period regarding the occurrence of forest fires through the analyses of FMC after rainfall episodes comparatively to the value observed before the episodes.

\section{Field measurements}

In the present study, FMC of dead foliage from Pinus pinaster and Eucalyptus globulus tree species and living shrub foliage and extremities from Calluna vulgaris and Chamaespartium tridentatum (that are very common in the forests of Central Portugal) was measured by field sampling throughout the year from 1996 to 2010. Samples were daily collected at Lousã during the summer months (June to September) and once or twice a week during the rest of the year (October to May), between 12:00h 
and 14:00h LST. FMC was determined by oven-drying the fuel samples for 24 hours at $105^{\circ} \mathrm{C}$, as presented in Figure 1. The total daily rainfall measured at the Lousã Weather Station obtained by the Portuguese Institute of Meteorology for the same period was used in the present analysis. Similar sampling was performed in Viseu (80km apart from Lousã) for the following species: dead foliage of Pinus pinaster and Eucalyptus globulus and living Calluna vulgaris from 2007 to 2010.

For FMC prediction after rainfall episodes, model evaluation was performed using data from of a series of rainfall episodes at Lousã and model validation was performed comparing predicted values with FMC measured in Viseu for well characterized rainfall episodes. For establishing the low risk period after the rainfall episodes data from Lousã and Viseu were used.

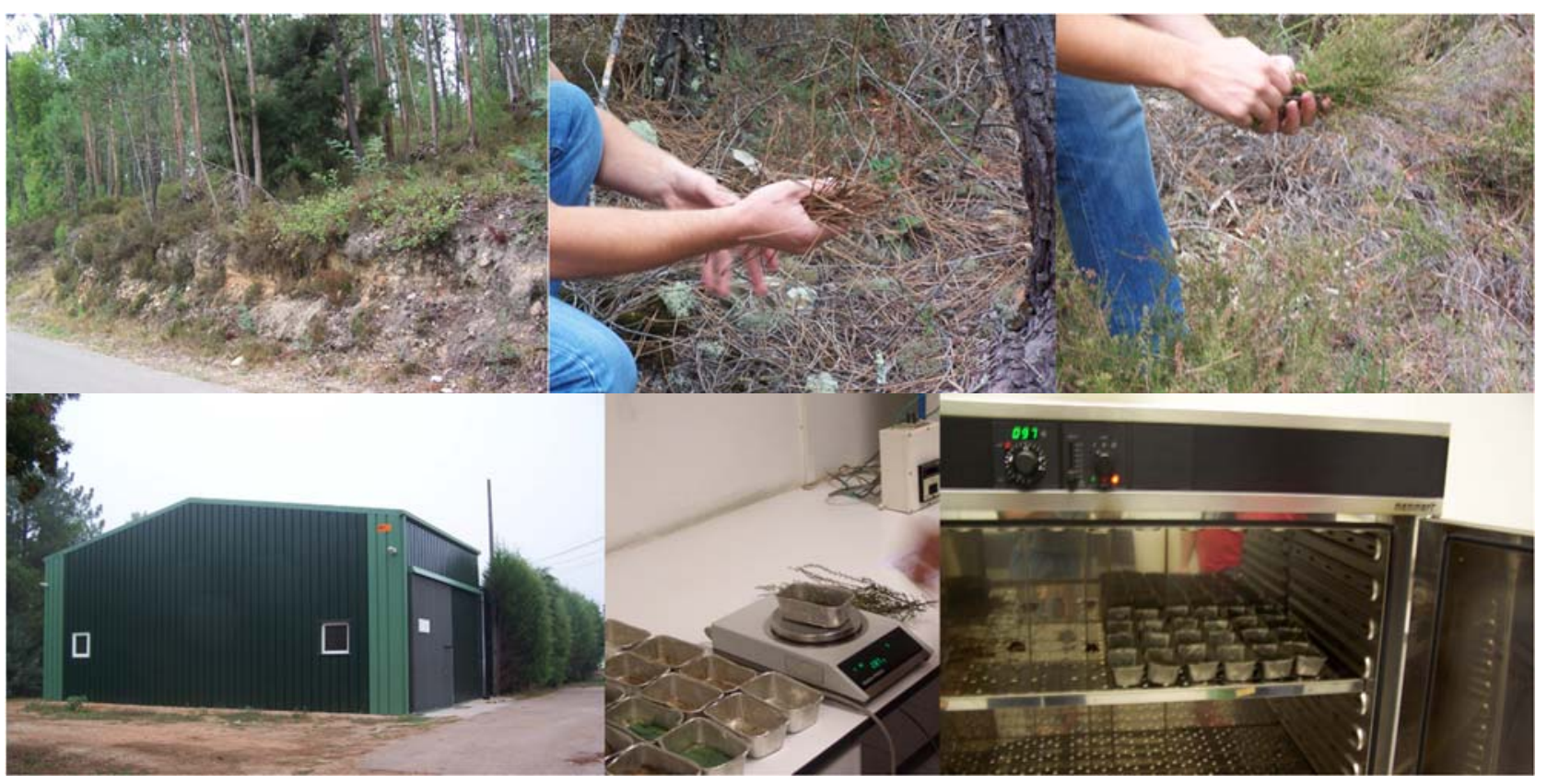

Figure 1. Sampling and determination procedures on the FMC research program of Lousã and Viseu

In Figure 2 some examples of studied rainfall episodes occurred in Lousã and Viseu are presented. As can be seen there are some rainfall episodes with only one day while in other examples there are several consecutive days of precipitation. In some of them rainfall intensity increased and in other cases rainfall intensity decreased.

Analysing all the available episodes occurred in Lousã and Viseu, depending on rainfall intensity and on the initial moisture content of forest fuels, after the rainfall episode we can establish period of time with low risk of fire ignition.

It can be observed that an episode with intensity up to $10 \mathrm{~mm} /$ day shows a 1 to 2 days safe period till it returns to the initial value of FMC before the episode. An episode with intensity higher than 10 $\mathrm{mm}$ /day can result in at least 3 days of low risk period. 

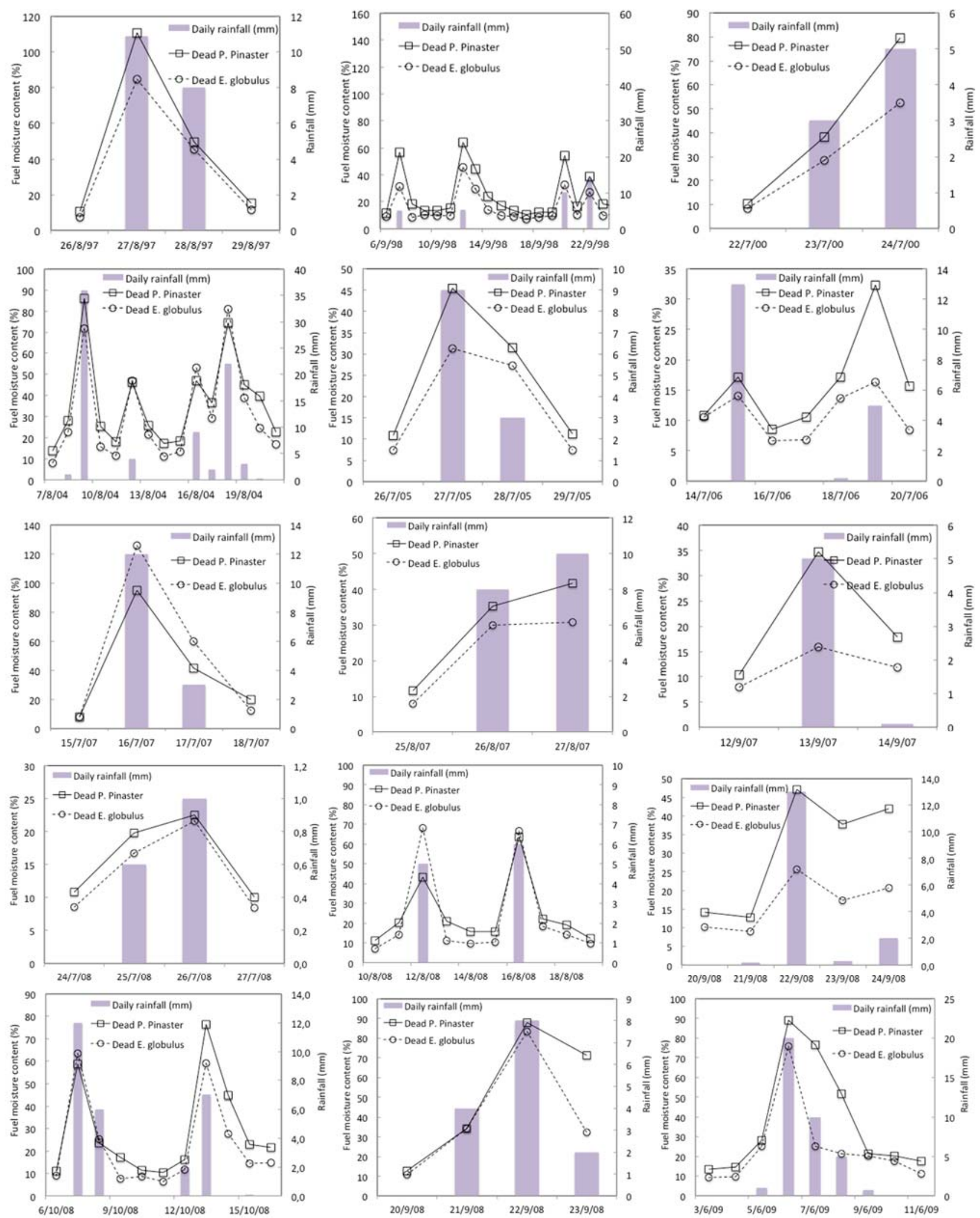

Figure 2. Examples of studied rainfall episodes that occurred in Lousã and Viseu. 


\section{FMC Variation Models}

As can be seen in Table 1, for a correlation analysis, the Spearman nonlinear correlation coefficients were calculated between the FMC variation, $\Delta m$ (variation between the FMC of one day and the FMC of the day before) and the rainfall intensity, $I_{d}$ (total rainfall of the last $24 \mathrm{~h}$ ), rainfall variation, $\Delta I$ (variation between the rainfall intensity of one day and the rainfall intensity of the day before) and the initial FMC, mo (FMC of the day before).

The correlation analysis shows that, for dead foliage (Pinus Pinaster and Eucalyptus globulus), rainfall intensity $I_{d}$ and rainfall variation $\Delta I$ have a significant positive correlation with FMC variation $\Delta m$ and a significant negative correlation with FMC variation/rainfall intensity $\Delta m / I_{d}$. For shrub foliage of Calluna vulgaris a medium positive correlation with $\Delta m$ and also a significant negative correlation with $\Delta m / I_{d}$ was observed.

Table 1. Correlation analysis between the FMC variation and rainfall intensity, rainfall variation and initial FMC

\begin{tabular}{|c|c|c|c|c|}
\hline & & & FMC variation & $\begin{array}{l}\text { FMC variation/ } \\
\text { Rainfall intensity }\end{array}$ \\
\hline & & & $\Delta \mathrm{m}(\%)$ & $\Delta \mathrm{m} / \mathrm{I}_{\mathrm{d}}\left(\% \cdot \mathrm{mm}^{-1}\right)$ \\
\hline \multirow{3}{*}{$\begin{array}{l}\text { Dead Pinus } \\
\text { pinaster }\end{array}$} & Rainfall intensity & $\mathrm{I}_{\mathrm{d}}(\mathrm{mm})$ & $0.683^{(* *)}$ & $-0.763^{(* *)}$ \\
\hline & Rainfall variation & $\Delta \mathrm{I}_{\mathrm{d}-\mathrm{d}-1}(\mathrm{~mm})$ & $0.692^{(* *)}$ & $-0.611^{(* *)}$ \\
\hline & Initial FMC & $\mathrm{m}_{0}$ & $0.059^{(\mathrm{ns})}$ & $-0.380^{(* *)}$ \\
\hline \multirow{3}{*}{$\begin{array}{c}\text { Dead Eucalyptus } \\
\text { globulus }\end{array}$} & Rainfall intensity & $\mathrm{I}_{\mathrm{d}}(\mathrm{mm})$ & $0.597^{(* *)}$ & $-0.750^{(* *)}$ \\
\hline & Rainfall variation & $\Delta \mathrm{I}_{\mathrm{d}-\mathrm{d}-1-1}(\mathrm{~mm})$ & $0.608^{(* *)}$ & $-0.656^{(* *)}$ \\
\hline & Initial FMC & $\mathrm{m}_{0}$ & $0.122^{\text {(ns) }}$ & $-0.361^{(* *)}$ \\
\hline \multirow{3}{*}{ Calluna vulgaris } & Rainfall intensity & $\mathrm{I}_{\mathrm{d}}(\mathrm{mm})$ & $0.316^{(* *)}$ & $-0.755^{(* *)}$ \\
\hline & Rainfall variation & $\Delta \mathrm{I}_{\mathrm{d}-\mathrm{d}-1}(\mathrm{~mm})$ & $0.328^{(* *)}$ & $-0.651^{(* *)}$ \\
\hline & Initial FMC & $\mathrm{m}_{0}$ & $0.291^{(* *)}$ & $0.025^{(\mathrm{ns})}$ \\
\hline \multirow{3}{*}{$\begin{array}{l}\text { Chamaespartium } \\
\text { tridentatum }\end{array}$} & Rainfall intensity & $\mathrm{I}_{\mathrm{d}}(\mathrm{mm})$ & $0.128^{(\mathrm{ns})}$ & $-0.815^{(* *)}$ \\
\hline & Rainfall variation & $\Delta \mathrm{I}_{\mathrm{d}-\mathrm{d}-1}(\mathrm{~mm})$ & $0.060^{(\mathrm{ns})}$ & $0.000^{(\mathrm{ns})}$ \\
\hline & Initial FMC & $\mathrm{m}_{0}$ & $0.041^{(\mathrm{ns})}$ & $-0.086^{(\mathrm{ns})}$ \\
\hline
\end{tabular}

Based on the Lousã FMC field measurements and considering the previous correlation analysis, three models were developed and tested, each one with the same purpose of determining the FMC $m_{d}$ of the day $d$ by adding a FMC increase/decrease value $\Delta m$ to the FMC observed before the episode $m_{0}$ as defined in Eqn 1.

$$
m_{d}=m_{0} \pm \Delta m
$$

A daily basis time resolution for FMC modelling was adopted, not considering crown interception, fuel immersion in water, changes of intensity and duration of rainfall with less than $24 \mathrm{~h}$ resolution. It is observed that for a given fuel with initial FMC value equal to $m_{o}$, expressed in [\%] in a given day $d$ if there is a rainfall with intensity $I_{d}$, expressed in [mm] on the previous 24 hours then there will be a FMC variation $\Delta m$.

In Model 1 we assume that for fine dead fuels this $\Delta m$ is an increase value to $m_{o}$ depending only on the amount of rainfall of day $d$ as defined in Eqn 2. 


$$
\Delta m=a_{1} \cdot I_{d}^{b_{1}}
$$

It was also found that $\Delta m$ could depend not only on $I_{d}$ but also on $m_{o}$.

We propose Model 2 to estimate the relationship between the increase in FMC and rainfall intensity expressed by $\Delta m / I_{d}$ and the initial FMC $m_{o}$ as defined in Eqn 3.

$$
\Delta m / I_{d}=a_{2} \cdot m_{0}^{b_{2}}
$$

Models 1 and 2 do not consider FMC change due to consecutive days with rainfall, which are observed quite often. For this purpose we propose Model 3 to take into account, not only the occurrence of rainfall in one day but also in two consecutive days with values $I_{d}$ and $I_{d-1}$, respectively for the last 24 hours and the previous 24 hours. Depending on the sign of rainfall variation $\Delta I=I_{d}-I_{d-1}$ we will have two situations:

(i) If $\Delta l>0$ then the FMC variation value $\Delta m$ is positive and we will have a moisture increase given by Eqn 4:

$$
\Delta m=a_{3} \cdot \Delta I_{d-d_{-1}}{ }^{b_{3}}
$$

(ii) If $\Delta l<0$ then the FMC variation value $\Delta m$ is negative and we will have a moisture decrease given by Eqn 5:

$$
\Delta m=-a_{4} \cdot\left|\Delta I_{d-d_{-1}}\right|^{b_{4}}
$$

Where $a_{1}, a_{2}, a_{3}, a_{4}, b_{1}, b_{2}, b_{3}$ and $b_{4}$ are empirical model parameters estimated with field measurements.

\section{Results}

In Table 2 the FMC prediction model parameters estimation defined in Eqn 2 to 5 are shown. This

\begin{tabular}{|c|c|c|c|c|c|c|c|c|}
\hline Model & Species & $i$ & $a_{i}$ & $\begin{array}{l}\text { Std. } \\
\text { dev. }\end{array}$ & $b_{i}$ & $\begin{array}{l}\text { Std. } \\
\text { dev. }\end{array}$ & $n$ & $\begin{array}{c}R^{2} \\
\text { adj. }\end{array}$ \\
\hline \multirow{3}{*}{ Model 1} & Dead Pinus pinaster & \multirow{3}{*}{1} & $15.180^{(* *)}$ & 1.100 & $0.445^{(* *)}$ & 0.037 & 14 & $\begin{array}{c}0.91 \\
7\end{array}$ \\
\hline & $\begin{array}{c}\text { Dead Eucalyptus } \\
\text { globulus }\end{array}$ & & $18.476^{(* *)}$ & 1.811 & $0.364^{(* *)}$ & 0.049 & 15 & $\begin{array}{c}0.79 \\
4\end{array}$ \\
\hline & Calluna vulgaris & & $22.961^{(* *)}$ & 1.458 & $0.211^{(* *)}$ & 0.029 & 9 & $\begin{array}{c}0.79 \\
4\end{array}$ \\
\hline \multirow{2}{*}{ Model 2} & Dead Pinus pinaster & \multirow{2}{*}{2} & $189.453^{(*)}$ & $\begin{array}{c}77.24 \\
6\end{array}$ & $\begin{array}{c}- \\
0.981^{(* *)}\end{array}$ & 0.137 & 9 & $\begin{array}{c}0.86 \\
3\end{array}$ \\
\hline & $\begin{array}{c}\text { Dead Eucalyptus } \\
\text { globulus }\end{array}$ & & $172.720^{* *}$ & $\begin{array}{c}44.37 \\
9\end{array}$ & $\begin{array}{c}- \\
0.960^{(* *)}\end{array}$ & 0.091 & 8 & $\begin{array}{c}0.94 \\
0\end{array}$ \\
\hline
\end{tabular}
estimation was performed using linear least squares fitting based on the field measurements. The graphical representation of the studied models is shown in Figure 3.

Table 2. Model parameters of Eqns 2 to 5 and statistical parameters 


\begin{tabular}{|c|c|c|c|c|c|c|c|c|}
\hline $\begin{array}{l}\text { Model } 3 \\
\text { Moisture } \\
\text { increase }\end{array}$ & $\begin{array}{c}\text { Dead Pinus pinaster } \\
\text { Dead Eucalyptus } \\
\text { globulus }\end{array}$ & 3 & $\begin{array}{l}14.146^{(* *)} \\
17.594^{(* *)}\end{array}$ & 1.338 & $0.495^{\left(^{*}\right)}$ & 0.070 & 5 & $\begin{array}{c}0.90 \\
6 \\
0.95 \\
0\end{array}$ \\
\hline $\begin{array}{l}\text { Model } 3 \\
\text { Moisture } \\
\text { decrease }\end{array}$ & $\begin{array}{c}\text { Dead Pinus pinaster } \\
\text { Dead Eucalyptus } \\
\text { globulus }\end{array}$ & 4 & $11.620^{(*)}$ & 1.337 & $0.398^{(* *)}$ & 0.052 & 11 & $\begin{array}{c}0.86 \\
6 \\
0.28 \\
2\end{array}$ \\
\hline
\end{tabular}
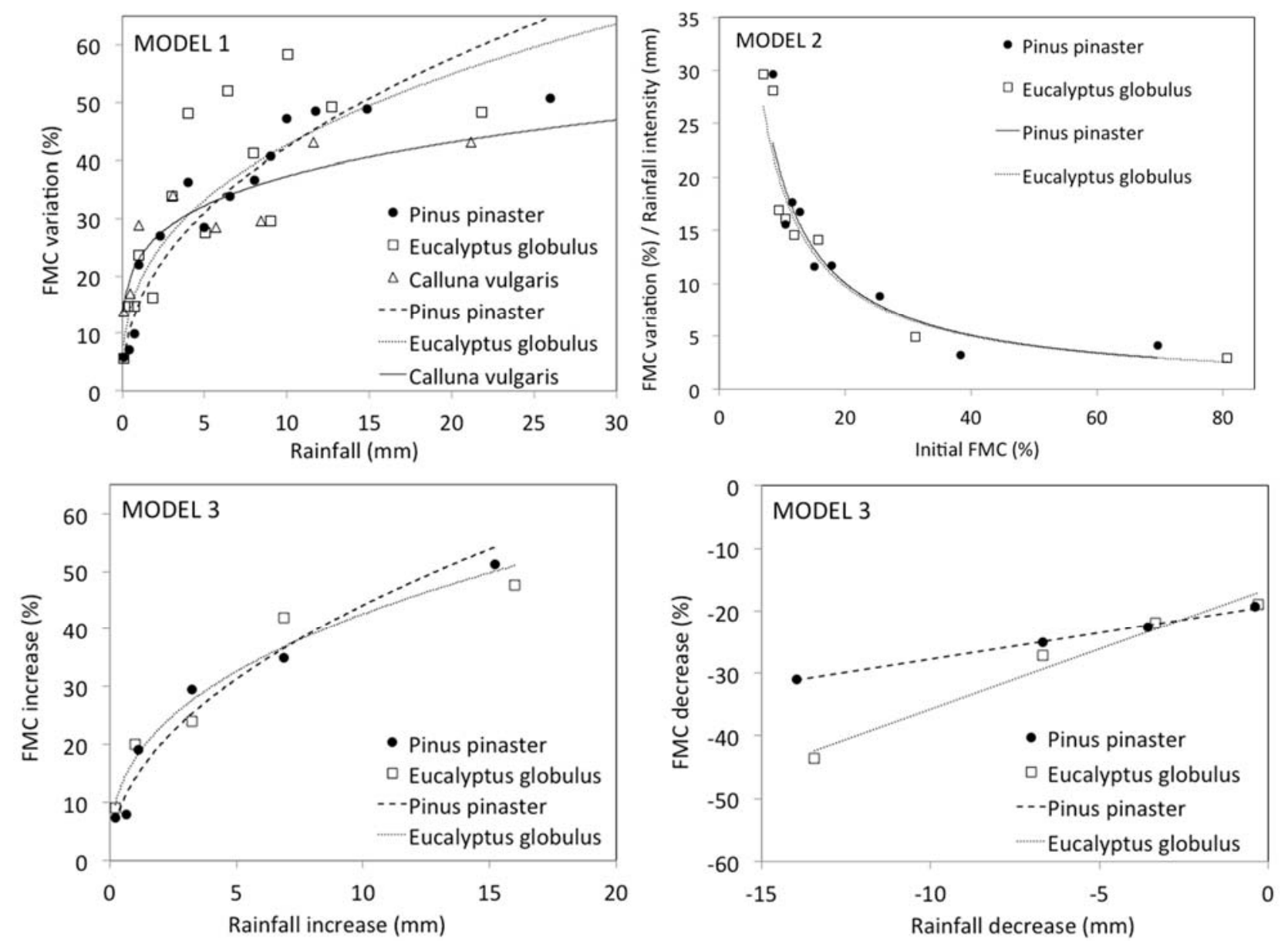

Figure 3. Graphical representation of the studied models

\section{Model validation}

In order to validate the previously developed models 1 to 5 the predicted FMC values with Pinus pinaster dead needles, Eucalyptus globulus dead leaves and Calluna vulgaris live extremities FMC measured in Viseu between 2007 and 2010 were compared.

In Figure 4, an example comparing predicted FMC values with the ones measured between July and September 2008, taking into account the rainfall effects is presented. Note that the predicted FMC values are calculated only when there is occurrence of rainfall.

Results of the Statistical model validation are presented inTable 3, comparing Viseu field measured values with predicted values, in terms of mean absolute error (MAE), root mean squared error (RMSE) and determination coefficient $\left(\mathrm{R}^{2}\right)$, for dead foliage (Pinus pinaster and Eucalyptus globulus) the best 
performance was obtained with Model 3 (MAE: 15.8\%, RMSE: $23.6 \%$ and $\mathrm{R}^{2}$ : 0.668 ). Although Model 2 showed a medium $\mathrm{R}^{2}(0.514)$ the MAE is very high $(46.6 \%)$, thus indicating that the difference between the model and the measured data is significant.

The results for shrub foliage of Calluna vulgaris, considered only in Model 1, that are shown in Table 3 did not exhibit a suitable performance (MAE: $44.5 \%$, RMSE: $64.2 \%$ and $\mathrm{R}^{2}: 0.287$ ).
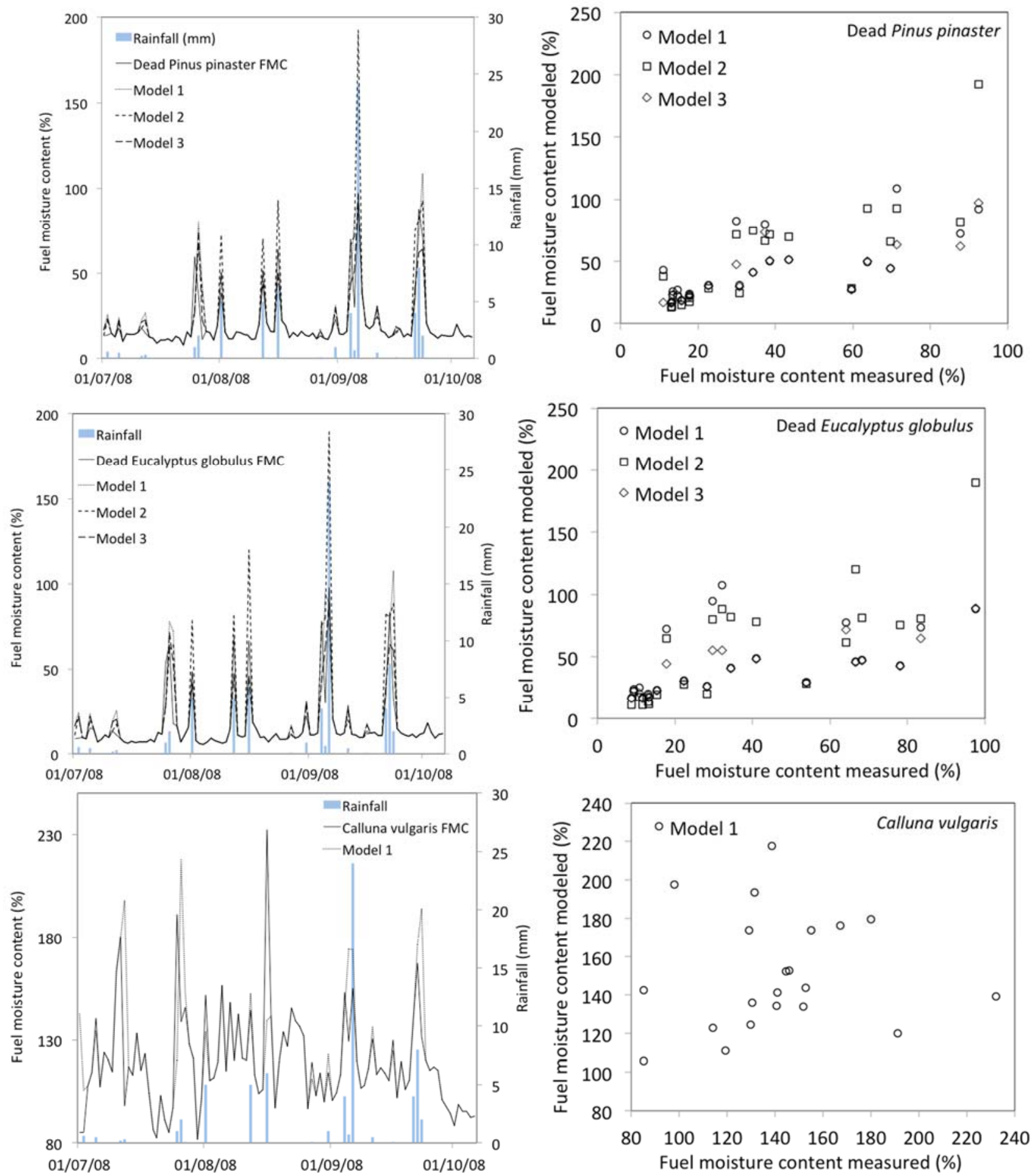

Figure 4. Example comparing predicted FMC values with the measured ones taking into account the rainfall effects. 
Table 3. Model validation results

\begin{tabular}{ccccc}
\hline Specie & Statistical parameters & Model 1 & Model 2 & Model 3 \\
\hline \multirow{2}{*}{ Pinus } & MAE & 0.223 & 0.466 & 0.158 \\
pinaster & RMSE & 0.304 & 0.794 & 0.236 \\
& $\mathrm{R}^{2}$ & 0.596 & 0.514 & 0.668 \\
\hline \multirow{2}{*}{ Eucalyptus } & $\mathrm{MAE}$ & 0.242 & 0.498 & 0.177 \\
globulus & $\mathrm{RMSE}$ & 0.323 & 0.848 & 0.224 \\
& $\mathrm{R}^{2}$ & 0.627 & 0.529 & 0.743 \\
\hline \multirow{2}{*}{ Calluna } & $\mathrm{MAE}$ & 0.445 & - & - \\
vulgaris & $\mathrm{RMSE}$ & 0.642 & - & - \\
& $\mathrm{R}^{2}$ & 0.287 & - & - \\
\hline
\end{tabular}

\section{Conclusion}

Although the influence of rainfall on forest fuel moisture content is quite complex we found that the simple assumptions that were made in the present study and the mathematical models that were proposed show suitable performances in the prediction of FMC change after rainfall episodes.

In the present study good results for dead foliage of Pinus pinaster and Eucalyptus globulus species prediction were obtained. In validation tests the best performance was obtained with Model 3, a model that takes into account, not only the occurrence of rainfall in one day but also in two consecutive days. Analysing all the available episodes that occurred in Lousã and Viseu, we found that a low risk period can be established after a rainfall episode. The duration of this period depends on rainfall intensity and on the initial value of moisture content of forest fuels. After an episode up to $10 \mathrm{~mm} /$ day a low period of one or two days can be expected while for an episode of more than $10 \mathrm{~mm} /$ day this duration can be extended to three days or more.

Further research has to be carried out to check the validity of the proposed models in other conditions and to compare their performance with that of other models.

\section{References}

Van Wagner CE (1987) Development and Structure of the Canadian Forest Fire Weather Index System. Canadian Forestry Service, Forestry Technical Report 35, Ottawa

Viegas DX, Viegas MT (1994) A relationship between rainfall and burned area for Portugal. International Journal of Wildland Fire, 4(1), 11-16. doi:10.1071/WF9940011

Viney NR (1991) A review of fine fuel moisture modelling. International Journal of Wildland Fire 1, 215-234. doi:10.1071/WF9910215. 